\title{
Chromosome numbers of invasive species of the Altai Republic flora. II
}

\author{
M. N. Lomonosova, E. Yu. Zykova, T. V. An'kova \\ Federal State Institution of Science Central Siberian Botanical Garden of Siberian Branch of RAS, Zolotodolinskaya str., 101, \\ Novosibirsk, 630090,Russia.E-mail:mlomonosova@mail.ru
}

Keywords: Altai Republic, Amaranthaceae, Asteraceae, Caryophyllaceae, chromosome numbers, invasive species, Lamiaceae, Onagraceae, Poaceae.

Summary. Chromosome numbers (2n) in 16 invasive plant species from the families Amaranthaceae, Asteraceae, Caryophyllaceae, Lamiaceae, Onagraceae and Poaceae are reported on the material from the Altai Republic for the first time. Among them, chromosome complements were first examined in Russia for Chaiturus marrubiastrum (L.) Ehrh. ex Reichenb. $(2 n=24)$ and Oenothera villosa Thunb. $(2 n=14)$. Five species: Amaranthus lividus L. $(2 n=34)$, Elisanthe noctiflora (L.) Rupr. $(2 n=24)$, Galeopsis speciosa Mill. $(2 n=16)$, Oenothera biennis L. $(2 n=14)$ and Bromus japonicus Thunb. $(2 n=14)$, were studied first from Siberia. The most part of the species studied are diploids. The general distribution and the history of floristic findings of these species in the Altai Republic are given. The data on chromosome numbers published earlier on the material from Russia are cited.

\section{Числа хромосом инвазионных видов во флоре Республики Алтай: сообщение 2}

\author{
М. Н. Ломоносова, Е. Ю. Зыкова, Т. В. Анькова \\ Федеральное государственное бюджетное учреждение науки «Центральный сибирский ботанический сад» \\ Сибирского отделения РАН, ул. Золотодолинская, 101, г. Новосибирск, 630090, Россия
}

Ключевые слова: инвазионные виды, Республика Алтай, числа хромосом, Amaranthaceae, Asteraceae, Caryophyllaceae, Lamiaceae, Onagraceae, Poaceae.

Аннотация. Приводятся данные о числах хромосом $(2 n)$ для 16 инвазионных видов из семейств Amaranthaceae, Asteraceae, Caryophyllaceae, Lamiaceae, Onagraceae, Poaceae, впервые полученные на материале из Республики Алтай. Впервые для России определены числа хромосом у Chaiturus marrubiastrum (L.) Ehrh. ex Reichenb. $(2 n=24)$ и Oenothera villosa Thunb. $(2 n=14)$, впервые для Сибири - у Amaranthus lividus L. $(2 n=34)$, Elisanthe noctiflora (L.) Rupr. $(2 n=24)$, Galeopsis speciosa Mill. $(2 n=16)$, Oenothera biennis L. $(2 n=14)$ и Bromи japonicus Thunb. $(2 n=14)$. Большинство изученных видов являются диплоидами. Для всех исследованных видов приводятся сведения по общему распространению, истории флористических находок на территории Республики Алтай и литературные данные по числам хромосом, полученные на материале с территории России.

The Altai Republic is currently one of the regions attracting a large number of tourists from different regions of Russia and other countries. As a result, the vegetation is exposed to significant anthropogenic impact, which contributes to invasion of a large number of alien species in the area and leads to further transformation in biological diversity of the flora. Invasive species, in their turn, may themselves undergo evolutionary changes in the new conditions. That is why, the comprehensive study and biological monitoring of alien species in the natural flora is becoming increasingly important. Given that 
polyploidy is a likely factor in species invasiveness (te Beest et al., 2012, and references therein), we have undertaken a detailed karyological research of all alien species in flora of the Altai Republic. This study is a part of the project on karyological investigation of the invasive flora of South Siberia and is a continuation of previous work (Zykova et al., 2018). We provide an information on the history of floristic studies on examined species at the territory of the Altai Republic, and in some cases - in Siberia. When referring to P. N. Krylov $(1909,1931,1949)$ we use the terminology of modern administrativeterritorial division. For all species, the references on chromosome numbers revealed on the material from Russia have been provided as well, as relevant information in the international databases "Ehe Chromosome Counts Database" (Rice et al., 2015) and "Index to Plant Chromosome Numbers" (Goldblatt, Johnson, 1979+) is reflected incompletely.

The ploidy level of samples was determined by direct count of chromosomes in metaphase on squash preparations of root meristem. All species were studied for the first time on the material collected in the Altai Republic. Seeds were germinated at $25^{\circ} \mathrm{C}$ (day) and $16{ }^{\circ} \mathrm{C}$ (night) on sterile sand. The root tips were pretreated for two hours with $0.2 \%$ colchicine water solution, fixed in $3: 1$ absolute ethanol-glacial acetic acid and stained with $1 \%$ acetic hematoxylin. Metaphase plates were observed under 100× magnification by the Axioscope 40 (Karl Zeiss, Axio Lab) and photographed by the AxiCam MRc 5 digital camera. The herbarium specimens (vouchers) are saved in the Herbarium of the Central Siberian Botanical Garden SB RAS (NS).

For species marked with an asterisk $(*)$, the chromosome number is determined for the first time in Russia, two asterisks $\left({ }^{* *}\right)$ - for the first time in Siberia.

\section{AMARANTHACEAE}

**Amaranthus lividus L. (A. blitum L.), $\mathbf{2 n}=\mathbf{3 4}$

"Russia, Altai Republic, Turochak district, vicinity of Turochak village, roadside, $52^{\circ} 15^{\prime} \mathrm{N}, 87^{\circ} 07^{\prime} \mathrm{E}$. 5 VIII 2016. E. Zykova, Z166-2816" (NS).

Annual. This species was found in all developed agricultural areas of the world. In the Altai Republic the first findings were in Gorno-Altaysk (Ilyin, Fedotkina, 2008) and Yaylyu village (Zolotukhin, 1983). Currently, it is a common garden weed occurring on fallow lands and waste places in GornoAltaysk, Mayma and Turochak districts (Zykova, 2015).
The chromosome number is determined first on Siberian material. The same number was obtained for Primorye Territory (Probatova, 2014, and references therein).

\section{Amaranthus retroflexus L., $2 n=32$}

"Russia, Altai Republic, Mayma district, vicinity of Rybalka village, wasteland at a construction site, $51^{\circ} 55^{\prime} \mathrm{N}, 85^{\circ} 51^{\prime} \mathrm{E}$. 2 VIII 2015. E. Zykova, Z206$3315^{\prime \prime}(\mathrm{NS})$.

Annual. The north-American species is distributed in all continents. It is a widespread invasive species in Russia including Siberia. In the Altai, $A$. retroflexus was firstly reported by Krylov (1909) from Kibisen village, the Chulyshman River valley near the Bashkaus River mouth and the Katu-Yaryk Pass. Nowadays, it is widespread in the Altai Republic (Zykova, 2015).

The same chromosome number was previously reported for Novosibirsk Region (Krasnikov, Lomonosova, 1990), Irkutsk Region (Chepinoga, 2014, and references therein; Probatova et al., 2016a), Amur Region (Probatova et al. 2006) and Primorye Territory (Probatova, 2014, and references therein) as well.

\section{ASTERACEAE}

\section{Bidens cernua L., $2 n=\mathbf{2 4}$}

"Russia, Altai Republic, Choya district, vicinity of Sugul village, wet roadside, $52^{\circ} 03^{\prime} \mathrm{N}, 86^{\circ} 15^{\prime} \mathrm{E} .25$ VIII 2012. E. Zykova, Z203-5412” (NS).

Annual. This Holarctic species is common in lowlands of the Altai Territory (Krylov, 1949; Silantyeva, 2013), from there it was apparently introduced to the Altai Republic, where the first finding was in 1949 in Choya village (NS!). Currently, this species occurs in northern districts of the Altai Republic often forming wide populations (Zykova, 2015, 2017).

This chromosome number confirms earlier counts from Irkutsk Region (Chepinoga, 2014, and references therein), Khabarovsk Territory (Probatova, Sokolovskaya, 1989) and Primorye Territory (Probatova, 2014, and references therein).

Conyza canadensis (L.) Cronq. (Erigeron canadensis L.), $\mathbf{2 n}=\mathbf{1 8}$

"Russia, Altai Republic, Choya district, vicinity of Choya village, wasteland, $52^{\circ} 02^{\prime} \mathrm{N}, 86^{\circ} 33^{\prime} \mathrm{E} .7$ VIII 2015. E. Zykova, Z284-3715” (NS); "Russia, Altai Republic, Turochak district, vicinity of UstLebed village, roadside, $52^{\circ} 17^{\prime} \mathrm{N}, 87^{\circ} 20^{\prime}$ E. 8 VIII 
2015. E. Zykova, Z283-4015" (NS); "Russia, Altai Republic, Shebalino district, vicinity of Cherga village, wasteland at the river bank $51^{\circ} 34^{\prime} \mathrm{N}, 85^{\circ} 34^{\prime} \mathrm{E}$. 20 VIII 2016. E. Zykova, Z167-4316" (NS); "Russia, Altai Republic, Chemal district, vicinity of Anos village, wasteland, $51^{\circ} 29^{\prime} \mathrm{N}, 85^{\circ} 56^{\prime}$ E. 16 VIII 2015. E. Zykova, Z285-4615" (NS) (fig. 1A).

Annual. North-American species introduced in all continents including polar areas (Nikitin, 1983). It is one of the most aggressive actively spreading adventive species. The first findings in the Altai Republic were made in Ust-Muny village (Krylov, 1949), later it was mentioned for Ust-Kan district (Ilyin, Fedotkina, 2008). According to Zykova (2015), C. canadensis is common now in the northern districts of the Altai Republic.

Our chromosome count matches the number reported on the material from Buryatia Republic and Irkutsk Region (Chepinoga, 2014, and references therein), Kurgan Region (Krasnikov, Korolyuk, 1995), Krasnodar Territory (Probatova et al., 2012) and Primorye Territory (Rostovtseva, 1979; Probatova, 2014, and references therein)

Pilosella aurantiaca (L.) F. W. Schultz et Sch. Bip., $2 n=36$

"Russia, Altai Republic, Ust-Koksa district, eastern spurs of the Kholzun Ridge, fur-pine forest, wet meadow, $1600 \mathrm{~m}, 50^{\circ} 01^{\prime} \mathrm{N}, 85^{\circ} 11^{\prime} \mathrm{E} .28$ VIII 2013. T. An'kova, Z216-2" (NS) (fig. 1B).

Perennial herb. Native area of this species includes West and Central Europe and Middle Asia, from where it is spread as ornamental plant to Eurasia, North America and New Zealand (Kamelin, 1973; Tupitsyna, 2004). Recently P. aurantiaca was found in the Altai Republic (Zykova, An'kova, 2017).

The same chromosome number was known from Leningrad city (Chuksanova et al., 1968), Novosibirsk Region (Krasnikov, Tupitsyna, 2004), Sakhalin Region (Probatova et al., 2007, 2017) and Komi Republic (Lavrenko et al., 1990).

Tripleurospermum inodorum (L.) Sch. Bip. (Matricaria perforata Mérat), $\mathbf{2 n}=\mathbf{3 6}$

"Russia, Altai Republic, Mayma district, M-52 highway between Souzga and Rybalka villages, wasteland near construction site, $51^{\circ} 55^{\prime} \mathrm{N}, 85^{\circ} 51^{\prime} \mathrm{E}$. 7 VI 2015. E. Zykova, Z141-0415" (NS); "Russia, Altai Republic, Mayma district, Kyzyl-Ozek village, wasteland near the bridge, $51^{\circ} 53^{\prime} \mathrm{N}, 86^{\circ} 00^{\prime} \mathrm{E}$. 7 VIII 2015. E. Zykova, Z147-3515” (NS) (fig. 1C).

Annual or biennial. Eurasian species distributed in all continents is one of the most widespread adventive species in Siberia. The first findings on the territory of the Altai Republic were in Kibisen, Yaylyu and Oyrot-Tura villages, and near Karakol Mount (Krylov, 1949). At present, it is common in the northern part of the Altai Republic spreading sometimes to central regions (Zykova, 2015).

Two chromosome complements in this species were revealed on the material from Russia. $2 n=$ 36 was mentioned from Novosibirsk Region (Krasnikov, Lomonosova, 1990), Irkutsk Region and Trans-Baikal Territory (Chepinoga, 2014, and references therein), Krasnoyarsk Territory (Stepanov, 1994), and Primorye Territory (Probatova, 2014, and references therein), $2 n=18$ - from Amur Region (Probatova et al., 2008a) and Primorye Territory (Probatova, 2014, and references therein).

\section{CARYOPHYLLACEAE}

**Elisanthe noctiflora (L.) Rupr. (Silene noctiflora L.), $2 n=24$

"Russia, Altai Republic, Shebalino district, vicinity of Cherga village, wasteland on the river bank, 51 $34^{\prime} \mathrm{N}, 85^{\circ} 34^{\prime}$ E. 20 VIII 2016. E. Zykova, Z168-4316" (NS).

Annual. European species now distributed in the most regions of South Siberia (Ebel et al., 2014). In the Altai Republic so far it was known from several villages: Elekmonar, Chemal (Krylov, 1931), Yaylyu (Zolotukhin, 1983), Ynyrga (Zuev, 1993), Paspaul (Studenikina, 2000). Now the species is common in the northern part of the Altai Republic and begins spreading southward (Zykova, 2015).

Our chromosome count is the first on the material from Siberia. The same chromosome number was reported earlier from Sakhalin Region (Probatova et al., 2007, and references therein).

\section{LAMIACEAE}

*Chaiturus marrubiastrum (L.) Ehrh. ex Reichenb., $2 n=\mathbf{2 4}$

"Russia, Altai Republic, Turochak district, vicinity of Turochak village, roadside, $52^{\circ} 15^{\prime} \mathrm{N}, 87^{\circ} 07^{\prime} \mathrm{E}$. 5 VIII 2015. E. Zykova, Z198-2816" (NS) (fig. 1D).

Annual or biennial. Eurasian species introduced elswhere. In the Altai Republic it has been recently found in Turochak village (Zykova, 2015). For several years, the species is actively distributed in disturbed habitats, where it often forms thickets. $C$. marrubiastrum occasionally enters in light forests.

The chromosome number is counted first in Russia. It confirms the only data previously reported from Romania (Tarnavschi, 1948). 
**Galeopsis speciosa Mill., 2n= 16

"Russia, Altai Republic, Mayma district, Podgornoe village, roadside, $52^{\circ} 01^{\prime} \mathrm{N}, 85^{\circ} 53^{\prime} \mathrm{E}$. $31 \mathrm{VII}$ 2016. E. Zykova, Z222-1916" (NS); "Russia, Altai Republic, Shebalino distr., vicinity of Cherga village, wasteland on the river bank, $51^{\circ} 34^{\prime} \mathrm{N}, 85^{\circ} 34^{\prime} \mathrm{E}$. 20 VIII 2016. E. Zykova, Z221-4316" (NS) (fig. $1 \mathrm{E})$.

Annual. Euro-Mediterranean species, spreading in Eurasia. In the Altai Republic G. speciosa was first found in the late XX century at the mouth of Sema River, and in Marchela and Anos river basins (Pshenichnaya, 1997). Now this species is actively spreading in Gorno-Altaysk city and Mayma district, less common in Chemal and Shebalino districts (Ilyin, Fedotkina, 2008; Zykova, Erst, 2012; Zykova, 2014b, 2015).

This is the first chromosome count in Siberian population, which agrees with the data reported for Amur Region (Sokolovskaya et al., 1986).

\section{ONAGRACEAE}

**Oenothera biennis L., $2 n=14$

"Russia, Altai Republic, Turochak district, vicinity of Ust-Lebed village, roadside, $52^{\circ} 17^{\prime} \mathrm{N}, 87^{\circ} 20^{\prime} \mathrm{E}$. 8 VIII 2015. E. Zykova, Z183-4015" (NS); "Russia, Altai Republic, Turochak district, vicinity of Turochak, wasteland, $52^{\circ} 17^{\prime} \mathrm{N}, 87^{\circ} 20^{\prime} \mathrm{E} .7$ VIII 2015 . E. Zykova, Z184-3815" (NS) (fig. 1F).

Biennial. North American species, settled in Eurasia. In the Altai Republic it is found in Gorno-Altaysk city (Zykova, 2002), Mayma, Chemal (Shaulo et al., 2010) and Turochak ( Zykova, 2017) districts. O. biennis occurs much less often than the following species of Oenothera.

The chromosome number is determined for the first time on Siberian material. The same data were obtained from Stavropol Territory (Magulayev, 1984) and Primorye Territory (Probatova et al., 2014a), as well as Sakhalin Region (Probatova et al., 2007, and references therein).

*Oenothera villosa Thunb., $2 n=14$

"Russia, Altai Republic, Mayma district, Rybalka village, wasteland at a construction site, $51^{\circ} 55^{\prime} \mathrm{N}$, 8551'E. 18 VIII 2015. E. Zykova, Z182-5215" (NS); "Russia, Altai Republic, Chemal district, vicinity of Chemal village, the Chemal riverside, $51^{\circ} 25^{\prime} \mathrm{N}, 86^{\circ} 00^{\prime}$ E. 29 VII 2012. E. Zykova, Z1952912" (NS) (fig. 1G).

Biennial. North American species spreading in all continents. In the Altai Republic O. villosa was found first in the 1980s in Ust-Koksa and Choya districts (Ebel, 2008), later - in Gorno-Altaysk city and
Mayma (Shaulo et al., 2010), Turochak (Zykova, 2015), Chemal (Zykova, 2014a) and Ulagan (Ebel, 2008; Zykova, 2017) districts. The species is quite active in the northern part of the Altai Republic, but in the central part only few locations were found.

The chromosome number is counted from Russia for the first time.

\section{POACEAE}

**Bromus japonicus Thunb., $2 n=14$

"Russia, Altai Republic, Mayma district, Mayma village, on pebble of roadside, $52^{\circ} 02^{\prime} \mathrm{N}, 85^{\circ} 54^{\prime} \mathrm{E} .18$ VII 2015. E. Zykova, Z204-1715" (NS) (fig. 1H).

Annual. European-W Asian species, as alien elsewhere. In the Altai Republic the first localities were found in 2009 in Gorno-Altaysk city (Shaulo et al., 2010) where this species now is actively propagating, and in Mayma district as well (Zykova, 2015).

The chromosome number is determined on the material from Siberia for the first time. The same data were obtained from the Crimea (Petrova, 1972), Dagestan Republic (Sokolovskaya, Probatova, 1979) and Primorye Territory (Probatova, 2014 and references therein).

\section{Eragrostis amurensis Prob., $2 n=\mathbf{4 0}$}

"Russia, Altai Republic, Chemal district, vicinity of Chemal village, the Chemal riverside near the bridge, $52^{\circ} 25^{\prime} \mathrm{N}, 86^{\circ} 00^{\prime}$ E. 30 VII 2016. E. Zykova, Z181-1516" (NS); "Russia, Altai Republic, Turochak district, vicinity of Turochak village, wasteland, $52^{\circ} 15^{\prime} \mathrm{N}, 87^{\circ} 07^{\prime}$ E. 6 VIII 2015. E. Zykova, Z172-3016" (NS); "Russia, Altai Republic, Shebalino district, vicinity of Cherga village, wasteland near the riverside, $51^{\circ} 34^{\prime} \mathrm{N}, 85^{\circ} 34^{\prime}$ E. 20 VIII 2016. E. Zykova, Z180-4316" (NS).

Annual. The species distribution range covers Central and East Siberia, the Far East, Manchuria. In the Altai Republic it was discovered in late XX century in Choya (Studenikina, 1999) and Ulagan (Pyak, Ebel, 2001) districts. Now this species is quite common in the northern region and is found in central part of the Altai Republic (Shaulo et al., 2010; Seregin, 2012; Zykova, 2014a, 2015, 2017).

The same chromosome number $(2 n=40)$ was determined from Irkutsk Region and Trans-Baikal Territory (Chepinoga, 2014, and references), Khabarovsk Territory (Probatova, Sokolovskaya, 1984).

\section{Hordeum jubatum L., $2 n=\mathbf{2 8}$}

"Russia, Altai Republic, Ulagan district, Aktash village, the Menka riverside, pebble, $50^{\circ} 19^{\prime} \mathrm{N}$, 


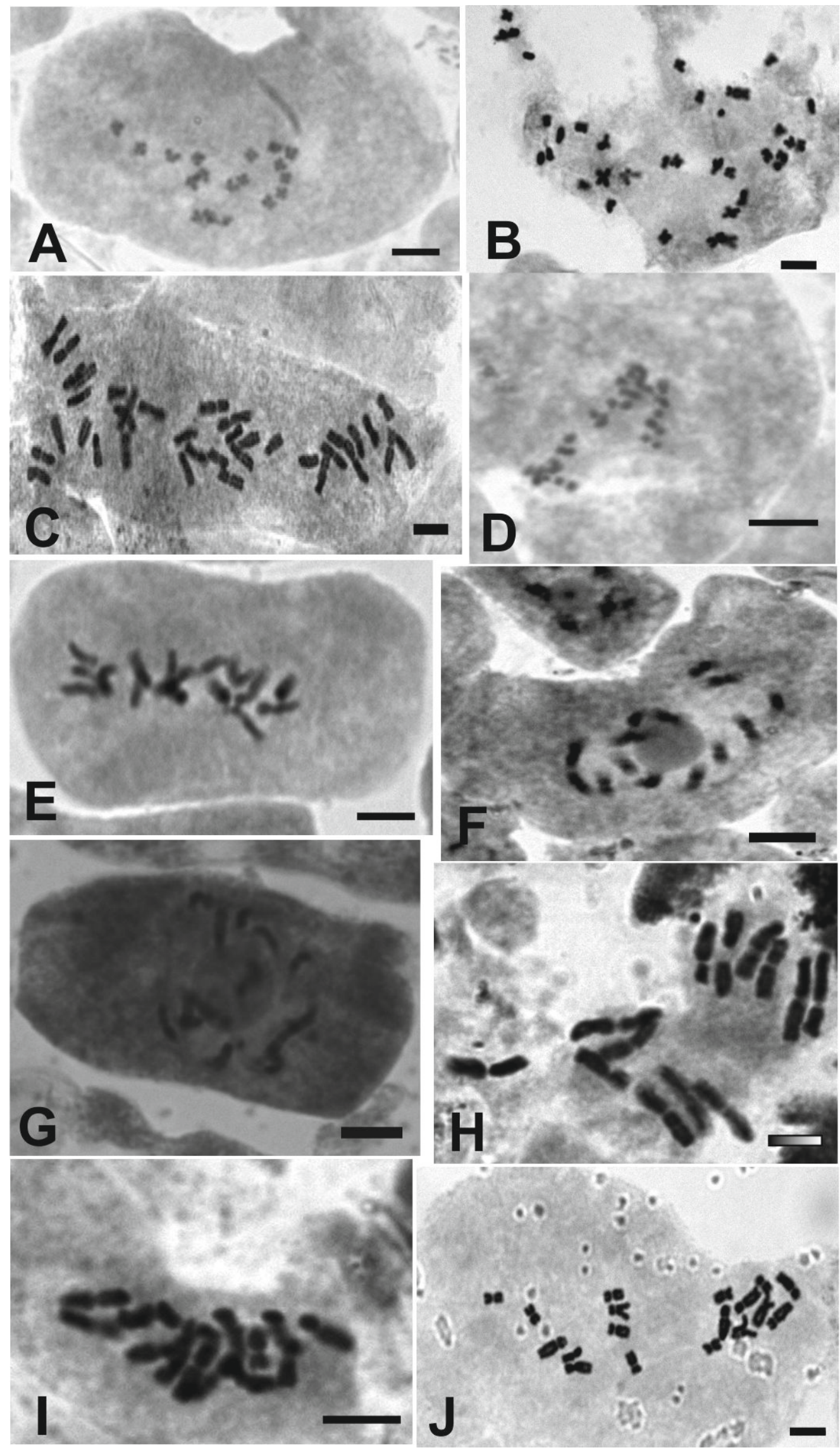

Fig. 1. Mitotic metaphase: A - Conyza canadensis, $2 n=18 ; \mathbf{B}$-Pilosella aurantiaca, $2 n=36 ; \mathbf{C}$-Tripleurospermum inodorum, $2 n=36 ; \mathbf{D}$ - Chaiturus marrubiastrum, $2 n=24 ; \mathbf{E}-$ Galeopsis speciosa, $2 n=16 ; \mathbf{F}-$ Oenothera biennis, $2 n=14 ; \mathbf{G}-$ Oenothera villosa, $2 n=14 ; \mathbf{H}$ - Bromus japonicus, $2 n=14 ; \mathbf{I}-$ Lolium multiflorum, $2 n=14 ; \mathbf{J}-$ Panicum ruderale, $2 n=18$. Scale $=5 \mu \mathrm{m}$. 
87³7'E. 10 VIII 2012. E. Zykova, Z75-4212” (NS); "Russia, Altai Republic, Ulagan district, Aktash village, streets, $50^{\circ} 19^{\prime} \mathrm{N}, 87^{\circ} 37^{\prime} \mathrm{E} .26$ VII 2013. E. Zykova, Z7-6813" (NS); "Russia, Altai Republic, Ulagan district, Aktash village, streets, $50^{\circ} 19^{\prime} \mathrm{N}, 87^{\circ} 37^{\prime}$ E. 25 VII 2015. E. Zykova, Z922315" (NS); "Russia, Altai Republic, Ulagan district, Ulagan village, flowerbed in the hospital's yard, $50^{\circ} 37^{\prime} \mathrm{N}, 87^{\circ} 57^{\prime}$ E. 16 VIII 2014. E. Zykova, Z8-5014" (NS); "Russia, Altai Republic, Ulagan district, Balyktuyul village, nearly Pazyryksk mounds, roadside $50^{\circ} 45^{\prime} \mathrm{N}, 88^{\circ} 02^{\prime} \mathrm{E}$. 16 VIII 2014. E. Zykova, Z6-5114" (NS); "Russia, Altai Republic, Kosh-Agach district, M-52 highway from CheganUzun to Aktash villages, roadside. 25 VII 2015. E. Zykova, Z93-2515" (NS); "Russia, Altai Territory, Altai district, camping «Turquoise Katun», close to Taldin caves, paths, $51^{\circ} 46^{\prime} \mathrm{N}, 85^{\circ} 43^{\prime} \mathrm{E} .31$ VII 2014. E. Zykova, Z14-2714" (NS).

Annual or perennial herb. As an alien, this species is distributed in all continents. In the Altai Republic $H$. jubatum was first discovered in Onguday (Pyak et al., 2000) and Ulagan (Pyak, Ebel, 2001) districts. Currently, it continues to propagate along the Chuya Tract (Ebel, 2008; Shaulo et al., 2010; Zykova, 2017). Besides, it is registered in Chemal district (Ilyin, Fedotkina, 2008; Zykova, 2015), Gorno-Altaysk city (Zykova, 2014b), Mayma and Ust-Koksa (Zykova, 2015) districts.

The same chromosome number was determined from Irkutsk Region (Chepinoga, 2014, and references therein), Magadan Region (Probatova, Sokolovskaya, 1982), Amur Region (Probatova et al., 2008a), Yakutia Republic (Zhukova et al., 1977; Probatova, Seledets, 2008), Chukotka (Zhukova, 1967; Zhukova, Petrovskiy, 1976; Petrovskiy, Zhukova, 1983), Primorye Territory (Probatova, 2014, and references therein), Buryatia Republic and Kamchatka Territory (Probatova et al., 2016b).

\section{Lolium multiflorum Lam., $2 n=14$}

"Russia, Altai Republic, Mayma district, the M-52 highway between Dubrovka and Karlushka villages, roadside, which in 2011 was poured and seeded with grass, $51^{\circ} 55^{\prime} \mathrm{N}, 85^{\circ} 51^{\prime} \mathrm{E} .18$ VIII 2013. E. Zykova, Z193-8213" (NS) (fig. 1I).

Annual or biennial. Euro-Mediterranean species, introduced elsewhere. In the Altai Republic it was imported together with seeds for coating roadside slopes along Chuya Tract in 2011 (Zykova, 2014b). It occurs along the motorway and adjacent meadows; registered only in Mayma district of the Altai Republic (Zykova, 2015).
Diploid. Earlier, the same chromosome number has been counted from Irkutsk Region (Chepinoga, 2014, and references therein), Sakhalin Region (Probatova et al., 2007, and references therein) and Amur Region (Probatova et al., 2014b).

Panicum ruderale (Kitag.) D. M. Chang (P. miliaceum L. auct.), $2 \boldsymbol{n}=\mathbf{1 8}$

"Russia, Altai Republic, Shebalino district, vicinity of Myyuta village, roadside, $51^{\circ} 26^{\prime} \mathrm{N}, 85^{\circ} 39^{\prime} \mathrm{E}$. 20 VIII 2016. E. Zykova, Z226-4216” (NS) (fig. $1 \mathrm{~J})$.

Annual. This weedy species is distributed in Eastern Europe, the Caucasus, Siberia, and settles in temperate zones of both hemispheres. In the Altai Republic it was found in the late XX century in Gorno-Altaysk city (Studenikina, 1999), Chemal (Nikiforova, 1990), Onguday (Pyak et al., 2000) and Ulagan (Pyak, Ebel, 2001) districts. Now it is quite common in the northern regions of the Altai Republic (Shaulo et al., 2010; Zykova, 2014a, 2015, 2017).

$2 n=18$ is a rare cytotype identified earlier from Slovakia (Murin, 1992) and Irkutsk Region (Chepinoga, 2014, and references therein). $2 n=36$ was obtained on the material from Irkutsk Region, Buryatia Republic and Trans-Baikal Territory (Chepinoga, 2014, and references therein), Altai Territory (Gnutikov et al. 2017) and Primorye Territory (Probatova et al., 2014, and references therein).

\section{Conclusion}

By now, chromosome numbers of 29 invasive species distributed in the Altai Republic were examined. Among them, the data for 16 species are represented in this study. For the first time Chaiturus marrubiastrum and Oenothera villosa have been studied on the material from Russia. The chromosome numbers of studied species are constant through their distribution range and diploid species prevail between. The exceptions are Tripleurospermum inodorum and Panicum ruderale, for which two chromosome complements are given in the literature. In recent years five polyploid species (Amaranthus lividus, A. retroflexus, Eragrostis amurensis, Hordeum jubatum and Tripleurospermum inodorum) have been introduced most actively in the Altai Republic, as well as lately discovered Pilosella aurantiaca, that is spreading in Turochak district very quickly now. A rarer diploid cytotype $(2 n=18)$ was found in Panicum ruderale which was revealed by previous authors as tetraploid $(2 n=36)$ in the vast majority of studied populations. 


\section{Acknowlegements}

The study was carried out in the framework of the Scientific Program № AAAA-A17-117012610055-3 of the Central Siberian Botanical Garden SB RAS and partially supported by the Russian Foundation for Basic Research (project No 16-04-01246 to E. Zykova).

\section{REFERENCES / ЛИTEPATУРA}

Chepinoga V. V. 2014. Chromosome numbers of plant species from Baikal Siberia. Nauka, Novosibirsk, 419 pp. [In Russian]. (Чепинога B. В. Хромосомные числа растений флоры Байкальской Сибири. Новосибирск: Наука, 2014. 419 c.)

Chuksanova N. A., Sveshnikova L. I., Alexandrova T. V. 1968. Data on karyology of the family Compositae Giseke. Tsitologiya 10(2): 198-206 [In Russian]. (Чуксанова Н. А., Свешникова Л. И., Александрова Т. В. 1968. Материалы к кариологии сложноцветных // Цитология, 1968. Т. 10, № 2. С. 198-206).

Ebel A. L. 2008. New and rare species of flowering plants to the flora of Altai mountain country. Turczaninowia 11, 4: 77-85 [In Russian]. (Эбель А. Л. Новые и редкие виды цветковых растений для флоры Алтайской горной страны // Turczaninowia, 2008. Т. 11, вып. 4. C. 77-85).

Ebel A. L., Strelnikova T. O., Kupriyanov A. N., Anenkhonov O. A., Ankipovich E. C., Antipova E. M., Verkhozina A. V., Efremov A. N., Zykova E. Yu., Mikhaylova S. I., Plikina N. V., Ryabovol S. V., Silantyeva M. M., Stepanov N. V., Terekhina T. A., Chernova O. D., Shaulo D. N. 2014. Invasive and potential invasive species of Siberia. Byull. Glavn. bot. sada (Moscow) [Bulletin of Main Botanical Garden] 1(200): 52-61 [In Russian]. (Эбель А. Л., Стрельникова Т. О., Куприянов А. Н., Аненхонов О. А., Анкипович Е. С., Антипова Е. М., Верхозина А. В., Ефремов А. Н., Зыкова Е. Ю., Михайлова С. И., Пликина Н. В., Рябовол С. В., Силантьева М. М., Степанов Н. В., Терехина Т. А., Чернова О. Д., Шауло Д. Н. Инвазионные и потенциально инвазионные виды Сибири // Бюл. Глав. ботан. сада, 2014. № 1 (вып. 200). С. 52-61).

Gnutikov A. A., Myakoshina Yu. A., Punina E. O., Rodionov A. V. 2017. A karyological study of grasses (Poaceae) of Altai. II. Turczaninowia 20, 2: 16-22 [In Russian]. (Гнутиков А. А., Мякошина Ю. А., Пунина Е. О., Родионов $\boldsymbol{A}$. В. Кариологическое исследование злаков (Роасеае) Республики Алтай и Алтайского края. Сообщение II // Turczaninowia, 2017. T. 20, вып. 2. C. 16-22). DOI: 10.14258/turczaninowia.20.2.2

Goldblatt P., Johnson D. E. (eds). 1979+. Index to plant chromosome numbers (IPCN). URL: http://www.tropicos.org/Project/IPCN (Accessed 31 May 2018).

Ilyin V. V., Fedotkina N. V. 2008. Sosudistyye rasteniya Respubliki Altay: annotirovannyy konspekt flory [Vascular plants of the Altai Republic: annotated outline of the flora]. Gorno-Altaysk, 290 pp. [In Russian]. (Ильин В. В., Федоткина Н. B. Сосудистые растения Республики Алтай: аннотированный конспект флоры. Горно-Алтайск, 2008. 290 c.).

Kamelin R. V. 1973. Florogeneticheskiy analiz yestestvennoy flory gornoy Sredney Azii [Florogenetic analysis of the natural flora of mountainous Central Asia]. Leningrad, 353 pp. [In Russian]. (Камелин Р. В. Флорогенетический анализ естественной флоры горной Средней Азии. Л., 1973. 353 с.).

Krasnikov A. A., Korolyuk E. A. 1995. Chromosome numbers in some members of the family Asteraceae from Siberian flora. Bot. Zhurn. (Moscow \& St. Petersburg) 80(4): 107 [In Russian]. (Красников А. А., Королюк Е. А. Числа хромосом некоторых представителей семейства Asteraceae флоры Сибири // Бот. журн., 1995. Т. 80, № 4. C. 107).

Krasnikov A. A., Lomonosova M. N. 1990. Chromosome numbers in representatives of some families of vascular plants in the flora of the Novosibirsk region. I. Bot. Zhurn. (Moscow \& Leningrad) 75(1): 116-118 [In Russian]. (Красников А. А., Ломоносова М. Н. Хромосомные числа представителей из некоторых семейств флоры Новосибирской области, 1 // Бот. журн., 1990. Т. 75, № 1. С. 116-118).

Krasnikov A. A., Tupitsyna N. N. 2004. Chromosome numbers of some species of Hieracium L. and Pilosella Hill. (Asteraceae) from Siberia. Bot. Zhurn. (Moscow \& St. Petersburg) 89(1): 132-133 [In Russian]. (Красников A. А., Тупицына Н. Н. Числа хромосом некоторых видов родов Hieracium L. и Pilosella Hill. (Asteraceae) из Сибири // Бот. журн., 2004. Т. 89, № 1. С. 132-133).

Krylov P. N. 1909. Amaranthus L. In: Flora Altaya i Tomskoy gubernii [Flora of the Altai and Tomsk province]. Vol. 5. Tomsk, 1142-1144 pp. [In Russian]. (Крылов П. Н. Amaranthus L. // Флора Алтая и Томской губернии. Томск, 1909. Т. 5. C. 1142-1144).

Krylov P. N. 1931. Melandryum Rohl. In: Flora Zapadnoy Sibiri [Flora of Western Siberia]. Vol. 5. Izdatelstvo Tomskogo Universiteta, Tomsk, 1073-1083 pp. [In Russian]. (Крылюв П. Н. Melandryum Rohl. // Флора Западной Сибири. Т. 5. Томск: изд-во ТГУ, 1931. С. 1073-1083).

Krylov P. N. 1949. Compositae. In: Flora Zapadnoy Sibiri [Flora of Western Siberia]. Vol. 11. Izdatelstvo Tomskogo Universiteta, Tomsk, 2649-3070 pp. [In Russian]. (Крылюв П. Н. Сотроsitae, Сложноцветные // Флора Западной Сибири. Т. 11. Томск: изд-во ТГУ, 1949. С. 2649-3070). 
Lavrenko A. N., Serditov N. P., Ulle Z. G. 1990. Chromosome numbers in some species of flowering plants of the Urals (the Komi Autonomous Soviet Socialist Republic). Bot. Zhurn. (Moscow \& Leningrad) 75(11): 1622-1624 [In Russian]. (Лавренко А. Н., Сердитов Н. П., Улле 3. Г. Числа хромосом некоторых видов цветковых растений Урала (Коми АССР) // Бот. журн., 1990. Т. 75, № 11. С. 1622-1624).

Magulayev A. V. 1984. Cytotaxonomic study in some flowering plants of the North Caucasus. Bot. Zhurn. (Moscow \& Leningrad) 69(4): 511-517 [In Russian]. (Магулаев А. Ю. Цитотаксономическое изучение некоторых цветковых растений Северного Кавказа // Бот. журн., 1984. Т. 69, № 4. С. 511-517).

Murín A. 1992. Karyological study of the Slovak flora XXIV. Acta Fac. Rerum Nat. Univ. Comenianae, Bot. 39 : 45-51.

Nikiforova O. D. 1990. Lolium L., Panicum L. In: Flora Sibiri [Flora of Siberia]. Vol. 2. Nauka, Novosibirsk, 162-163, 236-237 pp. [In Russian]. (Никифорова О. Д. Lolium L. - Плевел, Рanicum L. - Просо // Флора Сибири. T. 2. Новосибирск: Наука, 1990. С. 162-163, 236-237).

Nikitin V. V. 1983. Sornyye rasteniya flory SSSR [Weed plants of the USSR flora]. Leningrad, 452 pp. [In Russian]. (Никитин В. В. Сорные растения флоры СССР. Л., 1983. 452 с.).

Petrova O. A. 1972. Chromosome numbers of some grasses of the UTerritorynian SSR in connection with the living conditions of sprouting. In: Ways of an experimental study of the morphogenesis of higher plants. Kiyev, 16-18 pp. [In UTerritorynian]. (Петрова O. A. Хромосомні числа деяких злаків УРСР у зв'язку з умовами зростания. Шляхи експерементального дослідження морфогенезу вищих рослин. Киів, 1972. С. 16-18).

Petrovskiy V. V., Zhukova P. G. 1983. Polyploids and diploids in the vascular flora of the Wrangel Island. Bot. Zhurn. (Moscow \& Leningrad) 68(6): 749-760 [In Russian]. (Петровский В. В., Жукова П. Г. Полиплоиды и диплоиды во флоре сосудистых растений острова Врангеля // Бот. журн., 1983. Т. 68, № 6. С. 749-760).

Probatova N. S. 2014. Chromosome numbers in vascular plants of the Primorskii Territory (Russian Far East). Dalnauka, Vladivostok, 343 pp. [In Russian]. (Пробатова Н. С. Хромосомные числа сосудистых растений Приморского края. Владивосток: Дальнаука, 2014. 343 с.).

Probatova N. S., Barkalov V. Yu., Rudyka E. G. 2007. Caryology of the flora of Sakhalin and the Kurile Islands. Chromosome numbers, taxonomic and phytogeographical comments. Dalnauka, Vladivostok, 392 pp. [In Russian]. (Пробатова Н. С., Баркалов В. Ю., Рудыка Э. Г. Кариология флоры Сахалина и Курильских островов. Числа хромосом, таксономические и фитогеографические комментарии. Владивосток: Дальнаука, 2007. 392 с.).

Probatova N. S., Kazanovskiy S. G., Rudyka E. G. 2014a. IAPT / IOPB chromosome data 17 in Marhold (ed.) Taxon 63(5): 1153-1154. DOI: 10.12705/635.34

Probatova N. S., Kazanovskiy S. G., Rudyka E. G., Seledets V. P., Nechayev V. A. 2012. IAPT/IOPB chromosome data 13 in Marhold (ed.). Taxon 61(4): 899-902. URL: http://ibot.sav.sk/usr/Karol/docs/PDF_files/IAPT_IOPB_Chr_ data13.pdf

Probatova N. S., Krivenko D. A., Barkalov V. Yu. 2017. Further chromosome studies on the flora of Sakhalin and the Kurils, with additions from adjacent regions of the Russian Far East. Botanica Pacifica 6(2): 69-75. DOI: 10.17581/bp.2017.06209

Probatova N. S., Krivenko D. A., Ebel A. L. 2016a. IAPT/IOPB chromosome data 22 in Marhold, Kučera (eds.). Taxon 65(5): 1204. DOI: 10.12705/655.40

Probatova N. S., Rudyka E. G., Seledets V. P., Motorykina T. N. 2014b. Chromosome numbers in vascular plants from the Russian Far East: Amurskaya Region', Khabarovskii Territory, Primorskii Territory. Botanica Pacifica 3(2): 129-134. URL: http://botsad.ru/media/aux/bp/BP_2014_3_2_probatova.pdf

Probatova N. S., Rudyka E. G., Shatokhina A. V., Barkalov V. V., Kryukova M. V., Cyrenova D. Yu. 2006. Chromosome numbers of some plant species of the Primorye Territory and the Amur River basin. Bot. Zhurn. (Moscow \& St. Petersburg) 91(5): 785-804 [In Russian]. (Пробатова Н. С., Рудыка Э. Г., Шатохина А. В., Баркалов В. Ю., Крюкова М. В., Цыренова Д. Ю. Числа хромосом видов флоры Приморского края и Приамурья // Бот. журн., 2006. T. 91, № 5. C. 785-804).

Probatova N. S., Seledets V. P. 2008. IAPT/IOPB chromosome data 5 in Marhold (ed.). Taxon 57(2): 558-562. URL: http://www.iapt-taxon.org/files/iopb/IAPT_IOPB_Chr_data5.pdf

Probatova N. S., Seledets V. P., Chernyagina O. A. 2016b. Chromosome numbers in some species of Poaceae from Russia: further studies. Botanica Pacifica 5(2): 59-65. DOI: 10.17581/bp.2016.05201

Probatova N. S., Seledets V. P., Gnutikov A. A., Shatokhina A. V. 2008a. IAPT/IOPB chromosome data 6 in Marhold (ed.). Taxon 57(4): 1272-1273. URL: http://www.iapt-taxon.org/files/iopb/IAPT_IOPB_Chr_data6.pdf

Probatova N. S., Seledets V. P., Rudyka E. G. 2008b. IAPT/IOPB chromosome data 5 in Marhold (ed.). Taxon 57(2): 558-562. URL: http://www.iapt-taxon.org/files/iopb/IAPT_IOPB_Chr_data5.pdf

Probatova N. S., Sokolovskaya A. P. 1982. Synopsis of chromosome numbers in Poaceae from the Soviet Far East. I. The tribes Oryzeae, Brachypodieae, Triticeae. Bot. Zhurn. (Moscow \& Leningrad) 67(1): $62-70$ [In Russian]. (Пробатова Н. С., Соколовская А. П. Конспект хромосомных чисел Роасеае советского Дальнего Востока. 1. Трибы Oryzeae, Brachypodieae, Triticeae // Бот. журн., 1982. Т. 67, № 1. С. 62-70). 
Probatova N. S., Sokolovskaya A. P. 1984. Chromosome numbers of the representatives of the families Butomaceae, Papaveraceae, Poaceae from the USSR Far East. Bot. Zhurn. (Moscow \& Leningrad) 69(3): 410-412 [In Russian]. (Пробатова Н. С., Соколовская А. П. 1984. Числа хромосом представителей семейств Butomaceae, Papaveraceаe и Роасеае с Дальнего Востока СССР // Бот. журн., 1984. Т. 69, № 3. С. 410-412).

Probatova N. S., Sokolovskaya A. P. 1989. Chromosome numbers in vascular plants from Primorye Territory, the Amur region, Sakhalin, Kamchatka and the Kuril Islands. Bot. Zhurn. (Moscow \& Leningrad) 74(1): 120-123 [In Russian]. (Пробатова Н. С., Соколовская $\boldsymbol{A}$. П. Числа хромосом сосудистых растений из Приморья, Приамурья, Сахалина, Камчатки и Курильских островов // Бот. журн., 1989. Т. 74, № 1. С. 120-123).

Pshenichnaya I. N. 1997. Flora sosudistykh rasteniy Seminskogo khrebta (Altay) [Flora of vascular plants Seminsky Ridge (Altai)]. Altai University Publ., Barnaul, 228 pp. [In Russian]. (Пиеничная И. Н. Флора сосудистых растений Семинского хребта (Алтай). Барнаул: изд-во АГУ, 1997. 228 с.).

Pyak A. I., Ebel A. L. 2001. Materials to flora of Altai Mountains. Turczaninowia 4, 1-2: 86-94 [In Russian]. (Пяк А. И., Эбель А. Л. Материалы к флоре Алтая // Turczaninowia, 2001. Т. 4 (1-2). С. 86-94).

Pyak A. I., Ebel A. L., Ebel T. V. 2000. New and rare plants for flora of Altai region and Republic of Altai. Krylovia 2(1): 67-72 [In Russian]. (Пяк А. И., Эбель А. Л., Эбель Т. В. Новые и редкие виды растений во флоре Алтайского края и Республики Алтай // Krylovia, 2000. Т. 2, № 1. С. 67-72).

Rice A., Glick L., Abadi S., Einhorn M., Kopelman N., Salman-Minkov A., Mayzel J., Chay O., Mayrose I. 2015. The Chromosome Counts Database (CCDB) - a community resource of plant chromosome numbers. New Phytol. 206(1): 19-25. URL: http://ccdb.tau.ac.il (Accessed 31 May 2018).

Rostovtseva T. S. 1979. Chromosome numbers of some species of the family Asteraceae Dumort. Bot. Zhurn. (Moscow \& Leningrad) 64(4): 582-589 [In Russian]. (Ростовцева T. С. Числа хромосом некоторых видов семейства Asteraceae Dumort. // Бот. журн., 1979. Т. 64, № 4. С. 582-589).

Seregin A. P. 2012. Taxonomic circumscription and distribution of a glandular Eurasian entity from the Eragrostis pilosa complex (Poaceae). Phytotaxa 52: 8-20.

Shaulo D. N., Zykova E. Yu., Drachev N. S., Kuzmin I. V., Doron'kin V. M. 2010. Floristic findings in West and Middle Siberia. Turczaninowia 13, 3: 77-91 [In Russian]. (Шауло Д. Н., Зыкова Е. Ю., Драчев Н. С., Кузьмин И. В., Доронькин В. М. Флористические находки в Западной и Средней Сибири // Turczaninowia, 2010. Т. 13, вып. 3. С. 77-91).

Silantyeva M. M. 2013. Konspekt flory Altayskogo kraya [Check-list of the flora of Altayskiy Territory]. Second edition. Altay State University Publ., Barnaul, 520 pp. [In Russian]. (Силантьева М. М. Конспект флоры Алтайского края. 2-е изд. Барнаул: Изд-во АГУ, 2013. 520 с.).

Sokolovskaya A. P., Probatova N. S. 1979. Chromosome numbers of some grasses (Poaceae) in the USSR flora. III. Bot. Zhurn. (Moscow \& Leningrad) 64(9): 1245-1258 [In Russian]. (Соколовская А. П., Пробатова Н. С. Хромосомные числа некоторых злаков (Роасеае) флоры СССР. ІІІ // Бот. журн., 1979. Т. 64, № 9. С. 1245-1258).

Sokolovskaya A. P., Probatova N. S., Rudyka E. G. 1986. A contribution to the study of chromosome numbers and geographical distribution of some species of the family Lamiaceae in the Soviet Far East. Bot. Zhurn. (Moscow \& Leningrad) 71(2): 195-200 [In Russian]. (Соколовская А. П., Пробатова Н. С., Рудыка Э. Г. К изучению чисел хромосом и распространения некоторых видов семейства Lamiaceae на Дальнем Востоке CCCP // Бот. журн., 1986. T. 71, № 2. C. 195-200).

Stepanov N. V. 1994. Chromosome numbers of some higher plants taxa of the flora of Krasnoyarsk region. Bot. Zhurn. (Moscow \& St. Petersburg) 79(2): 135-139 [In Russian]. (Степанов Н. В. Числа хромосом некоторых таксонов высших растений флоры Красноярского края // Бот. журн., 1994. Т. 79, № 2. С. 135-139).

Studenikina E. Yu. 1999. Vysshiye sosudistyye rasteniya flory Biye-Katunskogo mezhdurechya v predelakh predgoriy i nizkogoriy Altaya [The higher vascular plants of flora of Biye-Katunsky interfluve within the foothills and lowmountains of Altai]. Altai University Publ., Barnaul, 121 pp. [In Russian]. (Студеникина Е. Ю. Высшие сосудистые растения флоры Бие-Катунского междуречья в пределах предгорий и низкогорий Алтая. Барнаул: изд-во АГУ, 1999. 121 с.). URL: http://docplayer.ru/31032114-Vysshie-sosudistye-rasteniya-flory-bie-katunskogo-mezhdurechya-v-predelah-predgoriy-i-nizkogoriy-Altaia.html

Studenikina E. Yu. 2000. On some rare plant species of the Biya-Katun watershed within the foothill and lowmountain areas of the Altai. Bot. Zhurn. (Moscow \& St. Petersburg) 85(1): 149-151 [In Russian]. (Студеникина $\boldsymbol{E}$. Ю. О редких видах Бие-Катунского междуречья в пределах предгорий и низкогорий Алтая // Бот. журн., 2000. T. 85, № 1. C. 149-151).

Tarnavschi I. T. 1948. Die Chromosomenzahlen der Anthophyten-Flora von Rumänien mit einem Ausblick auf das Polyploidie Problem. Bul. Grd. Bot. Univ. Cluj 28 (Suppl. I): 1-130.

te Beest M., Le Roux J. J., Richardson D. M., Brysting A. K., Suda J., Kubešová M., Pyšek P. 2012. The more the better? The role of polyploidy in facilitating plant invasions. Annals of Botany 109: 19-45.

Tupitsyna N. N. 2004. Yastrebinki Sibiri [Hawkweeds of Siberia]. Nauka, Novosibirsk, 208 pp. [In Russian]. (Tyпицына Н. Н. Ястребинки Сибири. Новосибирск: Наука, 2004. 208 с.). 
Zhukova P. G. 1967. Chromosome numbers in some species of plants of the north-eastern part of the USSR. II. Bot. Zhurn. (Moscow \& Leningrad) 52(7): 983-987 [In Russian]. (Жукова П. Г. Числа хромосом некоторых видов растений крайнего северо-востока СССР. II // Бот. журн., 1967. Т. 52, № 7. С. 983-987).

Zhukova P. G., Petrovskiy V. V. 1976. Chromosome numbers of some western Chukotka plant species, II. Bot. Zhurn. (Moscow \& Leningrad) 60(7): 963-969 [In Russian]. (Жукова П. Г., Петровский В. В. Хромосомные числа некоторых видов растений Западной Чукотки, II // Бот. журн., 1976. Т. 60, № 7. С. 963-969).

Zolotukhin N. I. 1983. Adventive plants in the Altai Reserve. Bot. Zhurn. (Moscow \& Leningrad) 68(11): 15281533 [In Russian]. (Золотухин Н. И. Адвентивные растения на территории Алтайского заповедника // Бот. журн., 1983. Т. 68, № 11. С. 1528-1533).

Zuev V. V. 1993. Elisanthe (Fenzl) Reichenb. In: Flora Sibiri [Flora of Siberia]. Vol. 6. Nauka, Novosibirsk, 59-62 pp. [In Russian]. (Зуев B. B. Elisanthe (Fenzl) Reichenb. - Скрытолепестник // Флора Сибири. Т. 6. Новосибирск: Наука, 1993. С. 59-62).

Zykova E. Yu. 2002. Flora of Gorno-Altaisk town and its environs. Bot. Zhurn. (Moscow \& St. Petersburg) 87(1): 93-99 [In Russian]. (Зыкова E. Ю. Флора города Горно-Алтайска и его окрестностей // Бот. журн., 2002. Т. 87, № 1. C. 93-99).

Zykova E. Yu. 2014a. New records of alien species in the Altai Republic flora. Byulleten MOIP. Otdel biologicheskiy [Bulletin of Moscow Society of Naturalists. Biological series] 119, 1: 80-81 [In Russian]. (Зыкова Е. Ю. Новые находки адвентивных видов во флоре Республики Алтай // Бюл. МОИП. Отд. биол., 2014а. Т. 119, вып. 1. С. 80-81). URL: http://herba.msu.ru/russian/journals/bmsn/archive/moip_2014_119_1.pdf

Zykova E. Yu. 2014b. New data on the distribution of alien species in the Altai Republic. Byulleten MOIP. Otdel biologicheskiy [Bulletin of Moscow Society of Naturalists. Biological series] 119, 6: 74-76 [In Russian]. (Зыкова E. Ю. Новые данные о распространении адвентивных видов во флоре Республики Алтай // Бюл. МОИП. Отд. биол., 2014б. Т. 119, вып. 6. С. 74-76). URL: http://herba.msu.ru/russian/journals/bmsn/archive/moip_2014_119_1. pdf

Zykova E. Yu. 2015. Alien flora of the Altai Republic. Rastitelnyy mir Aziatskoy Rossii [Plant Life of Asian Russia] 3(19): 72-87 [In Russian]. (Зыкова E. Ю. Адвентивная флора Республики Алтай // Растительный мир Азиатской России, 2015. № 3(19). С. 72-87). URL: http://www.izdatgeo.ru/pdf/rast/2015-3/72.pdf

Zykova E. Yu. 2017. New data on distribution of alien species in Altai. Byulleten MOIP. Otdel biologicheskiy [Bulletin of Moscow Society of Naturalists. Biological series] 122, 6: 64-66 [In Russian]. (Зыкова Е. Ю. Новые данные о распространении адвентивных видов на Алтае // Бюл. МОИП. Отд. биол., 2017. Т. 122, вып. 6. С. 64-66).

Zykova E. Yu., An'kova T. V. 2017. Additions to the alien flora of the Altai Republic. Byulleten MOIP. Otdel biologicheskiy [Bulletin of Moscow Society of Naturalists. Biological series] 122, 3: 77-78 [In Russian]. (Зыкова E. Ю., Анькова Т. В. Дополнения к адвентивной флоре Республики Алтай // Бюл. МОИП. Отд. биол., 2017. Т. 122, вып. 3. С. 77-78).

Zykova E. Yu., Erst A. S. 2012. Floristic findings of some rare and alien species in Siberia. Turczaninowia 15, 4: 34-40 [In Russian]. (Зыкова $\boldsymbol{E}$. Ю., Эрсm $\boldsymbol{A}$. $\boldsymbol{C}$. Находки некоторых редких и адвентивных видов растений в Сибири // Turczaninowia, 2012. Т. 15, вып. 4. С. 34-40).

Zykova E. Yu., Lomonosova M. N., An'kova T. V. 2018. Chromosome numbers of invasive species of the Altai Republic flora: post 1. Turczaninowia 21, 1: 41-51 [In Russian]. (Зыкова Е. Ю., Ломоносова М. Н., Анькова Т. В. Числа хромосом инвазионных видов во флоре Республики Алтай: сообщение 1 // Turczaninowia, 2018. T. 21 (1). C. 41-51). DOI: 10.14258/turczaninowia.21.1. 